\title{
Do Invasive Fire Ants Affect Habitat Selection within a Small Mammal Community?
}

\author{
Wendee N. Holtcamp, ${ }^{1}$ Christopher K. Williams, ${ }^{2}$ and William E. Grant ${ }^{3}$ \\ ${ }^{1}$ Department of Ecology and Evolutionary Biology, MS-170, Rice University, Houston, TX 77005, USA \\ ${ }^{2}$ Department of Entomology and Wildlife Ecology, University of Delaware, 250 Townsend Hall, Newark, DE 19716, USA \\ ${ }^{3}$ Department of Wildlife and Fisheries Sciences, Texas A\&M University, College Station, TX 77843-2258, USA
}

Correspondence should be addressed to Christopher K. Williams, ckwillia@udel.edu

Received 26 June 2010; Accepted 1 December 2010

Academic Editor: Andrew Sih

Copyright (C) 2010 Wendee N. Holtcamp et al. This is an open access article distributed under the Creative Commons Attribution License, which permits unrestricted use, distribution, and reproduction in any medium, provided the original work is properly cited.

Animals must balance foraging with the need to avoid predators and risky habitats that decrease their fitness, and at the same time they must cope with competitors vying for habitat and resources. We examined how habitat selection and population density of four native small mammals were altered by the presence of red imported fire ants (Solenopsis invicta). When population size was low, hispid cotton rats (Sigmodon hispidus) and pigmy mice (Baiomys taylori) as well as white-footed mice (Peromyscus leucopus) used the "safe", low fire ant habitat, as predicted by theories of density-dependent habitat selection. However, as fire ant population sizes expanded, cotton rats appeared to displace pigmy mice into the fire ant-dense grassland drainage while white-footed mice (Peromyscus leucopus) displaced all the other small mammals from low fire ant forest/brushland habitat.

\section{Introduction}

Understanding how animals select and utilize habitat is a key component of conservation and community ecology. Population size, competitor density, and predators all interact to determine habitat selection [1-7]. Animals must balance foraging with the need to avoid predators and risky habitats that decrease their fitness $[8,9]$, and at the same time they must cope with competitors vying for habitat and resources. This relationship between habitat heterogeneity, competitors, and predators provide a complex set of interactive effects on prey habitat use and population dynamics. Predators can affect the competitive interaction of prey species in two ways: a "density-mediated" or direct effect where there is an increase in mortality rates on prey species and a "behaviorally mediated" effect where prey alter behavior (e.g., habitat and resource use) [3, 10]. Additionally, if a nonnative species is introduced that is not in evolutionary equilibrium with the community, there is the potential for disruption of the predicted community dynamics $[11,12]$.

Red imported fire ants (Solenopsis invicta; hereafter fire ants) were inadvertently introduced to the port of
Mobile, Alabama in the 1930s and have since colonized over 100 million hectares [13]. Fire ants are known to affect small mammals both directly through mortality and indirectly through behavioral modification. Directly, fire ants have been known to consume small mammals alive in traps [14] and attack the eyes and mucous membranes of vertebrates, particularly the young or injured (reviewed in [15]). Indirectly, fire ants can reduce foraging area and effort by small mammals thus rendering high-quality habitats equivalent to risky habitats $[16,17]$. A recent meta-analysis suggests that indirect predator impacts (through traitmediated interactions effects on behavior and physiology) are typically greater than the direct impacts [18].

It is well known that many animals choose habitat that maximizes foraging efficiency and minimizes predation risk [19], and much theory and research has indicated a key role of density-dependent habitat selection in explaining patterns of small mammal distribution [20-22]. If small mammals choose habitat in relation to its quality and if high fire ant areas reduce habitat quality by reducing fitness [16, 17], one expects small mammals will select low fire ant areas. However, these impacts may depend on 
pre-existing habitat preferences and competitive interactions within and among species. The present study explores the relationship between habitat selection of 4 small mammal species while being influenced by interspecific competition and fire ant pressure. We have two primary objectives. First, we use spatially explicit regression models to examine how this small mammal community partitions three different macrohabitats with differing fire ant densities. Second, we use spatially explicit regression models to determine whether small mammal capture frequency was negatively correlated with fire ant foraging activity while considering microhabitat preferences.

\section{Study Area}

Sampling took place on a 0.64 ha study area on the Texas A\&M University Range Area, $10 \mathrm{~km}$ southwest of College Station, Texas, which lies within the Post Oak Savannah ecological region. The study area has been used for longterm research [14, 16, 23-27] and is divided into a 9-by9 grid, with $10 \mathrm{~m}$ spacing between grid points. Although the study area is relatively small, its importance as a longterm monitoring site provides a solid foundation for the goals of this paper. The study area is dominated by three habitat types: upland grassland, grassland drainage, and forest/brushland (Waer and Grant, unpub. ms.; Figure 1). Because of the proximity of three different habitat types, this study area has proved to be unique in that it supports four small mammal species: pigmy mice (Baiomys taylori), white-footed mice (Peromyscus leucopus), fulvous harvest mice (Reithrodontomys fulvescens), and hispid cotton rats (Sigmodon hispidus). Grant conducted trapping around different regions of the Texas A\&M University Range Area, and yet this particular trapping site is the only one in which multiple species were consistently captured, and the multispecies community has persisted since 1977 [23]. Whitefooted mice first appeared on the study site in 1980 and were captured every spring and fall season until 1992, when trapping ceased. Interestingly, white-footed mice colonized the study site around the time corresponding to when fire ants invaded this region of Texas. In 1975, fire ants had invaded Brazos County, where the study site resides [28]. Since 1977, vegetation on the study area has been consistently characterized and small mammal and fire ant populations have been sampled. The grassland drainage has twice the fire ant mound density and fire ant foraging activity compared with the upland grassland and forest/brushland (Figure 1). The region of highest fire ant density (grassland drainage) has remained relatively constant (Waer and Grant unpub. $\mathrm{ms})$.

\section{Methods}

The four small mammal species were sampled using one Sherman live trap $(7.5 \times 9 \times 23 \mathrm{~cm})$ baited with mixed cracked grain at each $10 \mathrm{~m}$ grid point (totaling 81 traps). Sampling occurred during three five-week periods, 17 nights in Sep-Oct 1991 (fall 1991), 15 nights in Mar-May 1992

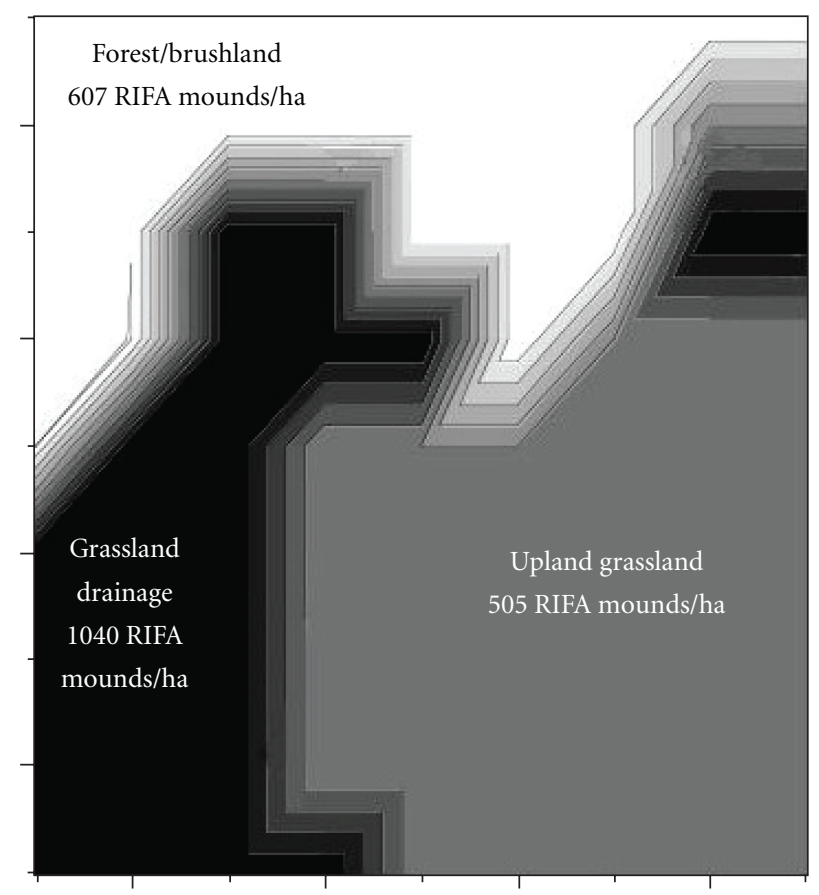

Figure 1: Placement of three macrohabitat types in the study area (measured by Waer and Grant (unpublished) in March 1989) with estimated red imported fire ant (RIFA) mound density for each.

(spring 1992), and 22 nights in Sep-Nov 1992 (fall 1992). Trapping was conducted for 4 nights per week unless weather conditions were severe. Traps were baited before dusk, left open until morning, and closed during the day. Granular ant poison (5\% Diazinon) was placed under each trap to prevent small mammal mortality [29]. Each animal was marked with a uniquely numbered ear tag and released at the point of capture. Procedures involving small mammal use were reviewed and approved by the Animal Use and Care Committee, Texas A\&M University as well as followed the American Society of Mammalogists guidelines.

Fire ant foraging activity [30] was measured at each of the 81 grid points, 4 times in fall 1991, twice in spring 1992, and 14 times in fall 1992. Plastic $35 \mathrm{~mm}$ film canisters were baited with 5 pieces of dry cat food and placed on their side at each grid point. After 10 minutes, containers were capped and collected; number of fire ants per container was counted at a later time. Average number of fire ants was calculated for each grid point and used as an index of fire ant foraging activity. The fire ant population on our study site was determined to be polygyne (multiple queen) because mound density over the study grid was 642 mounds/hectare in May 1989 (Waer and Grant unpub. ms, S. B. Vinson pers. comm.). Vegetation was sampled at each grid point within a $1.5 \mathrm{~m}$ radius circular frame during fall 1992. Percentage of ground surface covered by litter, bare soil, grass, forbs, and woody vegetation within each grid point quadrant was estimated visually and recorded. Depth of litter and height of woody and nonwoody vegetation also were measured and recorded. 
TABLE 1: Results of the best-fit spatial multiple linear regressions relating small mammal captures to three macrohabitat types and 3 other small mammal species (pigmy mice (BATA), white-footed mice (PERO), fulvous harvest mice (REFU), and hispid cotton rats (SIHI)). We report AIC weight and \% difference in AIC weights between the best-fit model (reported) and its most likely alternative model, and asterisks indicate significant explanatory variable in the best fitting model.

\begin{tabular}{|c|c|c|c|c|}
\hline Species & Season & Variables in the best-fit model & AIC weight (\% difference) & $R^{2}$ \\
\hline \multirow{3}{*}{$\begin{array}{l}\text { PIGMY MOUSE } \\
\text { (Baiomys taylori) }\end{array}$} & fall 1991 & (-) brushland/forest* & $61 \%(39 \%)$ & 0.24 \\
\hline & spring 1992 & $(-)$ grassland drainage & $57 \%(34 \%)$ & 0.06 \\
\hline & fall 1992 & (+) upland grassland* & $35 \%(14 \%)$ & 0.29 \\
\hline \multirow{3}{*}{$\begin{array}{l}\text { WHITE-FOOTED MOUSE } \\
\text { (Peromyscus leucopus) }\end{array}$} & fall 1991 & (+) brushland/forest*, (+) REFU* & $59 \%(37 \%)$ & 0.49 \\
\hline & spring 1992 & (+) brushland/forest*, (+) REFU & $41 \%(16 \%)$ & 0.39 \\
\hline & fall 1992 & $(+)$ brushland/forest* & $59 \%(35 \%)$ & 0.14 \\
\hline \multirow{3}{*}{$\begin{array}{l}\text { FULVOUS HARVEST MOUSE } \\
\text { (Reithrodontomys fulvescens) }\end{array}$} & fall 1991 & (+) PERO* & $40 \%(67 \%)$ & 0.26 \\
\hline & spring 1992 & $(-)$ brushland/forest* ${ }^{*}(+)$ PERO & $42 \%(14 \%)$ & 0.12 \\
\hline & fall 1992 & $(+)$ BATA & $60 \%(36 \%)$ & 0.03 \\
\hline \multirow{3}{*}{$\begin{array}{l}\text { HISPID COTTON RAT } \\
\text { (Sigmodon hispidus) }\end{array}$} & fall 1991 & $(+)$ brushland/forest & $60 \%(36 \%)$ & 0.10 \\
\hline & spring 1992 & $(+)$ upland grassland & $36 \%(18 \%)$ & 0.03 \\
\hline & fall 1992 & $(+)$ upland grassland ${ }^{*},(-)$ BATA & $41 \%(11 \%)$ & 0.12 \\
\hline
\end{tabular}

We used a Moran's I test using Splus-spatial module [31] to test for spatial autocorrelation, weighted by $20 \mathrm{~m}$ nearest neighbor. Because the majority of our data exhibited spatial autocorrelation $(P<.05$, B. taylori: fall 1991 and fall 1992; S. hispidus, P. leucopus, and fire ant activity: fall 1992 and spring 1992), spatial linear regression was most appropriate if macro and microhabitat variables affected small mammal capture frequency. Spatial linear regression captures spatial dependency between the independent variables and the dependent, between the dependent variables and a spatial lag of itself, or in the error terms. In the model

$$
Z_{i}=u_{i}+\delta,
$$

where $Z_{i}$ is a random process, small mammal capture frequency in our case, at site $i ; u_{i}$ is the mean capture frequency at site $i$, which is a linear model with covariates (average fire ant abundance and multiple time-independent environmental variables: \% litter cover, $\%$ ground, $\%$ grass, $\%$ woody cover, and woody vegetation height $(\mathrm{cm})) ; \delta \sim$ $N(0, \Sigma)$; and $\Sigma$ is the covariance matrix of random variables at all grid point sites. Conditional spatial autoregression (CAR) models were used for testing the small-scale variation to $\Sigma$

$$
\text { CAR: } \Sigma=(I-\rho N)^{-1} D \sigma,
$$

where $\rho$ and $\sigma$ are scalar parameters estimated by spatial regression, $N$ is a weight neighbor matrix, and $D$ is a diagonal matrix used to account for nonhomogeneous variance of the marginal distributions (our study area). A neighborhood structure was built assuming that spatial neighbors were defined as the trapping points that shared a common boundary, and neighbor weights were symmetric and equal to one. We used Akaike Information Criteria (AIC) model selection and Akaike weights to find the best-fit model [32]. We conducted a macrohabitat analysis using spatial linear regression, as above, to correlate small mammal captures of each species with each of three habitat types (Figure 1) and with the other small mammal species.

\section{Results}

Over the course of the study, the number of capture events (including repeat captures of individuals) were: 225 pigmy mice, 279 white-footed mice, 182 hispid cotton rats, and 52 fulvous harvest mice. Capture frequency of pigmy mice was the highest in fall of 1991 and low in other seasons (Figure 2). When their population size was high in fall 1991, pigmy mice were captured in the fire ant-dense grassland drainage habitat as frequently as in the upland grassland, while in spring and fall 1992 when their population sizes were low, they were never captured in the fire ant-dense habitat (Figure 2). Supporting this, the AIC best-fit modeling predicted an avoidance of brushland/forest in fall 1991. However, pigmy mice also showed a nonsignificant avoidance of grassland drainage in spring 1992 and a significant preference of upland grassland in fall 1992 (Figure 2, Table 1). Considering microhabitat and fire ant presence, pigmy mice showed additional variability. On average, they were found in areas with less bare ground and woody vegetation with lower height (Table 2).

Capture frequency of white-footed mice was the highest in spring 1992 and low in the other two seasons (Figure 2). White-footed mice were captured most often in brushland/forest across all seasons; however, in spring 1992 when their population sizes were high, they were increasingly captured in upland grassland and grassland drainage (Figure 2). Supporting this, the AIC best-fit modeling predicted whitefooted mice use macrohabitats with brushland/forest and fulvous harvest mice (Table 1). White-footed mice were not correlated with fire ants in any season, but were consistently correlated with woody vegetation characteristics (\% woody vegetation and height of woody vegetation) in the multiple seasons where red imported fire ants were less abundant (Figure 2, Table 2).

Capture frequency of fulvous harvest mice was very low in fall of 1991 and fall 1992 while moderate in spring 1992 (Figure 2). Although they appeared to be 

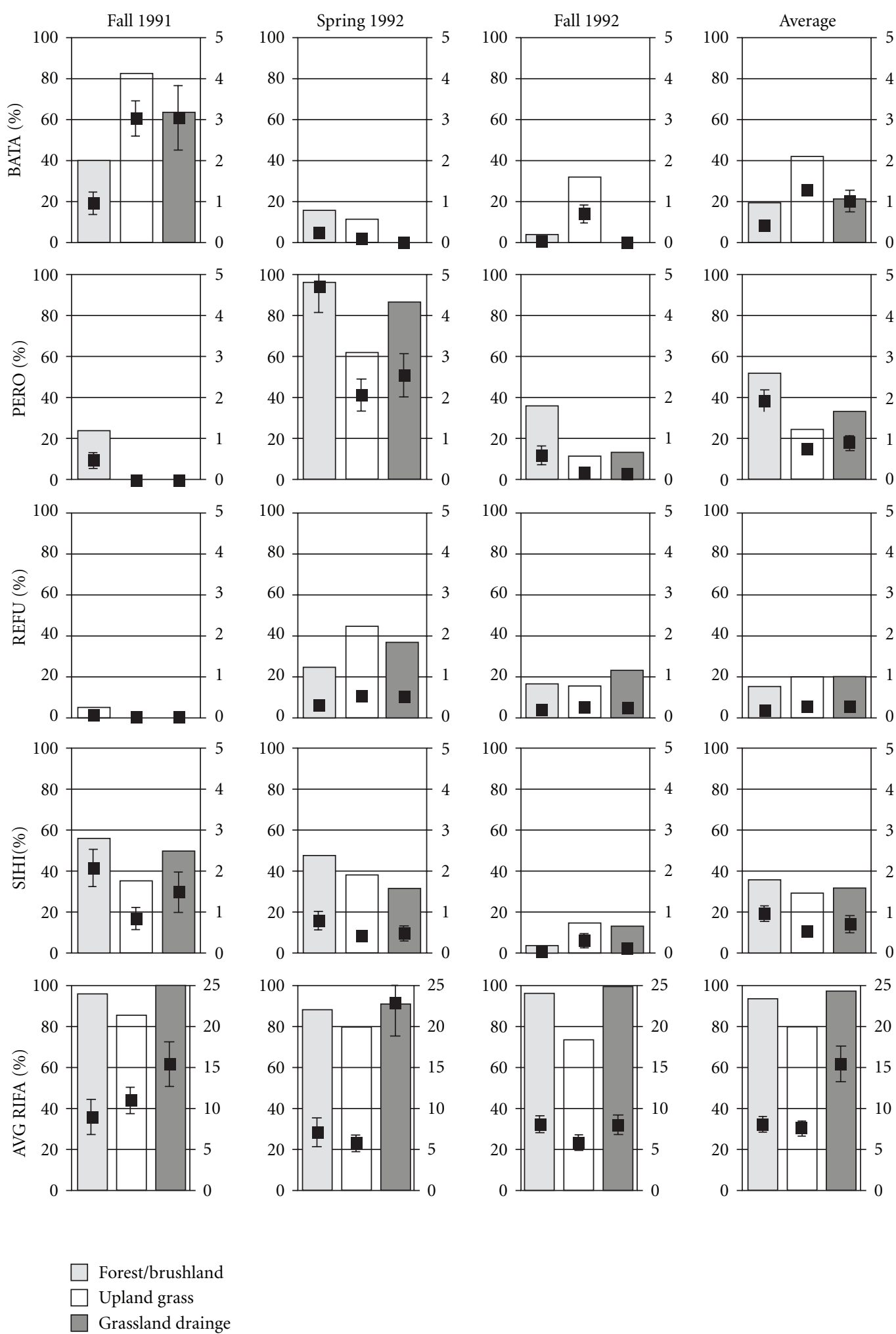

FIGURE 2: Columns indicate the mean proportion of each of the three habitat types (forest/brushland, upland grassland, and grassland drainage) occupied by pigmy mice (BATA), white-footed mice (PERO), fulvous harvest mice (REFU), hispid cotton rats (SIHI), and red imported fire ants (RIFA), Texas A\&M University Range Area, fall 1991, spring 1992, and fall 1992. Points indicate mean abundance ( \pm SE) per trapping point $\left(100 \mathrm{~m}^{2}\right.$ area $)$ in each of the three habitat types. 
TABLE 2: Results of the best-fit spatial multiple linear regressions relating small mammal captures to average red imported fire ant (RIFA) foraging activity and five microscale habitat characteristics. Asterisks indicate significant explanatory variable in the best fitting model. We report AIC weight and \% difference in AIC weights between the best-fit model (reported) and its most likely alternative model.

\begin{tabular}{|c|c|c|c|c|}
\hline Species & Season & Variables in the best-fit model & AIC weight (\% difference) & $R^{2}$ \\
\hline \multirow{3}{*}{$\begin{array}{l}\text { PIGMY MOUSE } \\
\text { (Baiomys taylori) }\end{array}$} & fall 1991 & $(-) \%$ ground $*,(+)$ litter depth & $24 \%(10 \%)$ & 0.14 \\
\hline & spring 1992 & $(-) \%$ litter, $(+) \%$ woody, $(-)$ woody ht* & $32 \%(6 \%)$ & 0.22 \\
\hline & fall 1992 & $(+) \%$ grass* & $53 \%(24 \%)$ & 0.12 \\
\hline \multirow{3}{*}{$\begin{array}{l}\text { WHITE-FOOTED MOUSE } \\
\text { (Peromyscus leucopus) }\end{array}$} & fall 1991 & $(+)$ woody ht* & $48 \%(16 \%)$ & 0.43 \\
\hline & spring 1992 & $(+) \%$ woody* & $56 \%(33 \%)$ & 0.27 \\
\hline & fall 1992 & $(-) \%$ litter, $(-)$ litter depth* & $44 \%(17 \%)$ & 0.19 \\
\hline \multirow{3}{*}{$\begin{array}{l}\text { FULVOUS HARVEST MOUSE } \\
\text { (Reithrodontomys fulvescens) }\end{array}$} & fall 1991 & $(-) \%$ litter*, (+) \% woody ht* & $43 \%(20 \%)$ & 0.19 \\
\hline & spring 1992 & $(+) \%$ litter & $45 \%(18 \%)$ & 0.05 \\
\hline & fall 1992 & $(+) \%$ litter & $57 \%(31 \%)$ & 0.07 \\
\hline \multirow{3}{*}{$\begin{array}{l}\text { HISPID COTTON RAT } \\
\text { (Sigmodon hispidus) }\end{array}$} & fall 1991 & (-) RIFA, (+) \% woody & $42 \%(14 \%)$ & 0.11 \\
\hline & spring 1992 & $(+) \%$ woody & $56 \%(31 \%)$ & 0.06 \\
\hline & fall 1992 & $(+)$ woody ht & $53 \%(27 \%)$ & 0.01 \\
\hline
\end{tabular}

distributed relatively evenly throughout the three habitat types (Figure 2), AIC modeling found avoidance for brushland/forest macrohabitats when capture frequency was higher in spring 1992, (Table 1). Inconsistent with this finding, fulvous harvest mice also showed a positive correlation with white-footed mice presence (which predicted preference for brushland/forest). Fulvous harvest mice were not correlated with fire ants in any season (Table 2) and only showed a significant avoidance of litter in fall 1991 (while showing a nonsignificant preference for litter in the following 2 seasons).

Hispid cotton rat capture frequency was moderate in fall 1991 and spring 1992 and was low in fall 1992 (Figure 2). Hispid cotton rats were captured across all habitats across all seasons (Figure 2). Supporting this, the AIC best-fit modeling found nonsignificant preference for brushland/forest in fall 1991 while exhibiting preference in upland grassland in the remaining two seasons (Table 1). Fire ants only weakly influenced microhabitat preference. Additionally, cotton rats were correlated with woody vegetation characteristics (\% woody vegetation and height of woody vegetation) in the multiple seasons where red imported fire ants were less abundant (Figure 2, Table 2).

\section{Discussion}

Small mammals spatially distributed themselves such that white-footed mice preferentially utilized forest/brushland, while pigmy mice and cotton rats used grassland habitats, especially low fire ant upland grassland habitat over the fire ant-dense grassland drainage. When population sizes of all small mammals were low in fall 1992, pigmy mice and cotton rats preferred the low fire ant upland grassland and showed a weak negative association with each other indicating a potential competitive interaction. When population sizes were larger in fall 1991, pigmy mice showed equal utilization of upland grassland and the fire ant-dense grassland drainage, whereas cotton rats appear to show preference for upland grassland. Additionally during this time, we observed a negative correlation between the abundance of cotton rats and the mean abundance of fire ants presumably because they were forced into riskier habitats. As predicted by theory, these species appear to select the safe habitat when rare [8].

Pedersen et al. [27] found pigmy mice did not alter habitat use when fire ants were removed and remained in high and low fire ant regions, whereas captures of cotton rats increased in fire ant removal areas and decreased in fire ant present areas. This suggests an interaction between the two species. If cotton rats were superior competitors, they would select the high-quality (low fire ant) habitat while pigmy mice might be forced to remain in lower quality habitat. Pigmy mice are not immune to fire ant impacts: they select burrows in low fire ant areas [33], and in monogyne fire ant populations, fire ant removal increased captures of pigmy mice [25]. Also, Raun and Wilks [34] showed that cotton rats aggressively displace pigmy mice into marginal areas.

Harvest mice appear to more equally utilize all habitats. Kincaid and Cameron [35] showed that competition had minimal effects on habitat and resource use between cotton rats and fulvous harvest mice. Harvest mice are known as tree-dwelling creatures, although they forage on the ground [36], but perhaps this reduces the competitive interactions with other species [37] as well as moderates the impact of fire ants on their habitat selection.

Theory suggests that shared predators may increase the number of species that can occupy a region by reinforcing habitat preferences $[10,38]$. Competitive interaction, such as foraging behavior, has the potential to be altered by predation risk and may lead to habitat partitioning in species differing in their susceptibility to predation. This interaction has the potential to allow a unique competitive coexistence that would not have occurred in the absence of the predation risk [39-42], a fact observed in fire ant/small mammal interactions $[16,17]$. The invasion of fire ants, which created a shared predation risk, may have enabled white-footed mice to successfully establish a population on the study site, by pushing other small mammals into alternate habitats. 
With the exception of Mills et al. [43] research examining predator/competitive interactions of native and invasive fish, this is the first study to examine the tritrophic effect of an invasive species predation on the interactive equilibrium between multiple prey species use of habitat. We believe our results provide support for Kotler and Holt [3] "behaviorally mediated" competitive effect where a predator has the potential to alter prey species habitat and resource use. However, because of the inherent complexity of this system (spatial, temporal, and 5-species interactions) and the lack of spatial replication, we recognize that our results may be limited. It is for this reason, we encourage future researchers to improve on this research in three ways. First, future researchers should replicate this study using controlled removal experiments to validate the results observed here. Second, future researchers should comprehensively evaluate how fire ants influence small mammal fitness rather than just apparent habitat use. Orrock and Danielson [17] indicated that fitness could be affected by fire ant presence, since fire ant presence reduced small mammal use of otherwise high-quality foraging patches. Third, there is a need to evaluate the demographic distribution of the population in areas of high and low fire ant density. For example, are the individuals that use high fire ant density patches subadults? Are transients more likely to be caught in high fire ant areas than residents? Seeking the individual response to fire ant dispersion should help to further elucidate the mechanisms underlying small mammal response to this biological invader.

\section{Acknowledgments}

We gratefully acknowledge Fred Smeins for vegetation sampling advice and S. Bradleigh Vinson for identification of the fire ant population and insight into the fire ant invasion dynamics. Comments by John Orrock, Owen Gilbert, Paul Harcombe, Bruce Milne, and an anonymous reviewer greatly improved the manuscript. We also thank the students and teaching assistants of Animal Ecology lab and all others who assisted with field work, and the Department of Rangeland Ecology and Management for access to the study site. Lastly, we thank National Science Foundation Graduate Research Fellowship for funding of W. Holtcamp during this research.

\section{References}

[1] S. D. Fretwell and H. L. Lucas, "On territorial behavior and other factors influencing habitat distribution in birds," Acta Biotheoretica, vol. 19, no. 1, pp. 16-36, 1970.

[2] M. L. Rosenzweig, "Hummingbird isolegs in an experimental system," Behavioral Ecology and Sociobiology, vol. 19, no. 5, pp. 313-322, 1986.

[3] B. P. Kotler and R. D. Holt, "Predation and competition: the interaction of two types of species interactions," Oikos, vol. 54, no. 2, pp. 256-260, 1989.

[4] K. J. Halama and R. D. Dueser, "Of mice and habitats: tests for density-dependent habitat selection," Oikos, vol. 69, no. 1, pp. 107-114, 1994.
[5] G. Shenbrot, B. Krasnov, and S. Burdelov, "Densityindependent habitat distribution caused by densitydependent habitat selection," Evolutionary Ecology Research, vol. 8, no. 7, pp. 1277-1290, 2006.

[6] M. L. Oatway and D. W. Morris, "Do animals select habitat at small or large scales? An experiment with meadow voles (Microtus pennsylvanicus)," Canadian Journal of Zoology, vol. 85, no. 4, pp. 479-487, 2007.

[7] G. Shenbrot, B. Krasnov, and S. Burdelov, "Long-term study of population dynamics and habitat selection of rodents in the Negev Desert," Journal of Mammalogy, vol. 91, no. 4, pp. 776786, 2010.

[8] A. Sih, "Prey refuges and predator-prey stability," Theoretical Population Biology, vol. 31, no. 1, pp. 1-12, 1987.

[9] J. S. Brown, "Patch use as an indicator of habitat preference, predation risk, and competition," Behavioral Ecology and Sociobiology, vol. 22, no. 1, pp. 37-47, 1988.

[10] R. D. Holt, "Predation, apparent competition, and the structure of prey communities," Theoretical Population Biology, vol. 12, no. 2, pp. 197-229, 1977.

[11] J. H. Brown, "Patterns, modes, and extents of invasions by vertebrates," in Biological Invasions: A Global Perspective, J. A. Drake, H. A. Mooney, F. Di Castri et al., Eds., pp. 85-110, John Wiley \& Sons, Chichester, UK, 1989.

[12] D. Simberloff, "Which insect introductions succeed and which fail," in Biological Invasions: A Global Perspective, J. A. Drake, H. A. Mooney, F. Di Castri et al., Eds., pp. 61-76, John Wiley \& Sons, Chichester, UK, 1989.

[13] S. B. Vinson and A. A. Sorensen., Imported Fire Ants: Life History and Impact, Texas Department of Agriculture, Austin, Tex, USA, 1986.

[14] M. P. Masser and W. E. Grant, "Fire ant-induced trap mortality of small mammals in east-central Texas," Southwestern Naturalist, vol. 31, pp. 540-542, 1986.

[15] C. R. Allen, D. M. Epperson, and A. S. Garmestani, "Red imported fire ant impacts on wildlife: a decade of research," American Midland Naturalist, vol. 152, no. 1, pp. 88-103, 2004.

[16] W. N. Holtcamp, W. E. Grant, and S. B. Vinson, "Patch use under predation hazard: effect of the red imported fire ant on deer mouse foraging behavior," Ecology, vol. 78, no. 1, pp. 308317, 1997.

[17] J. L. Orrock and B. J. Danielson, "Rodents balancing a variety of risks: invasive fire ants and indirect and direct indicators of predation risk," Behavioural Ecology, vol. 140, no. 4, pp. 662667, 2004.

[18] E. L. Preisser, D. I. Bolnick, and M. F. Benard, "Scared to death? The effects of intimidation and consumption in predator-prey interactions," Ecology, vol. 86, no. 2, pp. 501-509, 2005.

[19] S. L. Lima and L. M. Dill, "Behavioral decisions made under the risk of predation: a review and prospectus," Canadian Journal of Zoology, vol. 68, no. 4, pp. 619-640, 1990.

[20] D. W. Morris, "Ecological scale and habitat use," Ecology, vol. 68, no. 2, pp. 362-369, 1987.

[21] D. W. Morris, "Tests of density-dependent habitat selection in a patchy environment," Ecological Monographs, vol. 57, no. 4, pp. 269-281, 1987.

[22] M. L. Rosenzweig and Z. Abramsky, "Detecting densitydependent habitat selection," American Naturalist, vol. 126, no. 3, pp. 405-417, 1985.

[23] W. E. Grant, P. E. Carothers, and L. A. Gidley, "Small mammal community structure in the postoak savanna of east-central Texas," Journal of Mammalogy, vol. 66, pp. 589-594, 1985. 
[24] M. J. Killion and W. E. Grant, "Scale effects in assessing the impact of imported fire ants on small mammals," Southwestern Naturalist, vol. 38, pp. 393-396, 1993.

[25] M. J. Killion, W. E. Grant, and S. B. Vinson, "Response of Baiomys taylori to changes in density of imported fire ants," Journal of Mammalogy, vol. 76, no. 1, pp. 141-147, 1995.

[26] D. K. Ferris, M. J. Killion, K. P. Ferris, W. E. Grant, and S. B. Vinson, "Influence of relative abundance of red imported fire ants (Solenopsis invicta) on small mammal captures," Southwestern Naturalist, vol. 43, no. 1, pp. 97-100, 1998.

[27] E. K. Pedersen, T. L. Bedford, W. E. Grant et al., "Effect of red imported fire ants on habitat use by hispid cotton rats (Sigmodon hispidus) and northern pygmy mice (Baiomys taylori)," Southwestern Naturalist, vol. 48, no. 3, pp. 419-426, 2003.

[28] A. M. A. Callcott and H. L. Collins, "Invasion and range expansion of imported fire ants (Hymenoptera: Formicidae) in North America from 1918-1995," Florida Entomologist, vol. 79, no. 2, pp. 240-248, 1996.

[29] R. H. Chabreck, B. U. Constantin, and R. H. Hamilton, "Use of chemical ant repellants during small mammal trapping," Southwestern Naturalist, vol. 31, pp. 109-110, 1986.

[30] S. D. Porter and W. R. Tschinkel, "Foraging in Solenopsis invicta (Hymenoptera: Formicidae): effects of weather and season," Environmental Entomology, vol. 16, pp. 802-808, 1987.

[31] S. P. Kaluzny, S. C. Vega, T. P. Cardoso, and A. A. Shelly, "S+ Spatial Stats User's Manual," Version 1.0, Seattle, Wash, USA, MathSoft. 226pp, 1996.

[32] K. P. Burnham and D. R. Anderson, Model Selection and Inference-A Practical Information Theoretic Approach, Springer, New York, NY, USA, 1998.

[33] M. J. Killion, Small mammal response to red imported fire ant removal in a grassland community, M.S. thesis, Texas A\&M University, College Station, Tex, USA, 1992.

[34] G. G. Raun and B. J. Wilks, "Natural history of Baiomys taylori in southern Texas and competition with Sigmodon hispidus in a mixed population," Texas Journal of Science, vol. 16, pp. 28 49, 1964.

[35] W. B. Kincaid and G. M. Cameron, "Effects of species removal on resource utilization in a Texas rodent community," Journal of Mammalogy, vol. 63, no. 2, pp. 229-235, 1982.

[36] D. J. Schmidly, Texas Mammals East of the Balcones Fault Zone, Texas A\&M University, College Station, Tex, USA, 1983.

[37] S. R. Spencer and G. N. Cameron, "Reithrodontomys fulvescens," Mammalian Species, vol. 174, pp. 1-7, 1982.

[38] R. D. Holt and J. H. Lawton, "The ecological consequences of shared natural enemies," Annual Review of Ecology and Systematics, vol. 25, pp. 495-520, 1994.

[39] H. H. Caswell, "Predator-mediated coexistence: a nonequilibrium model," American Naturalist, vol. 112, pp. 127-154, 1978.

[40] I. Hanski, "Predator-mediated coexistence," Annales Entomologica Fennici, vol. 42, pp. 33-35, 1983.

[41] E. E. Werner, J. F. Gilliam, D. J. Hall, and G. G. Mittelbach, "An experimental test of the effects of predation risk on habitat use in fish," Ecology, vol. 61, pp. 233-242, 1983.

[42] J. J. Hughes, D. Ward, and M. R. Perrin, "Predation risk and competition affect habitat selection and activity of Namib desert gerbils," Ecology, vol. 75, no. 5, pp. 1397-1405, 1994.

[43] M. D. Mills, R. B. Rader, and M. C. Belk, "Complex interactions between native and invasive fish: the simultaneous effects of multiple negative interactions," Oecologia, vol. 141, no. 4, pp. 713-721, 2004. 

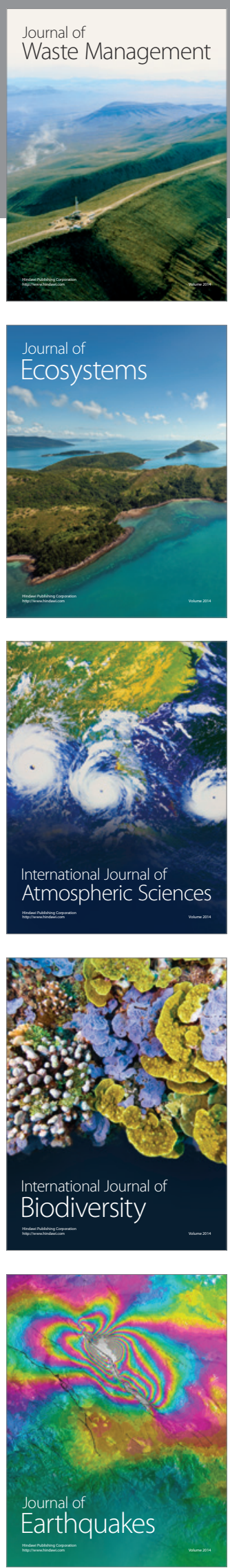
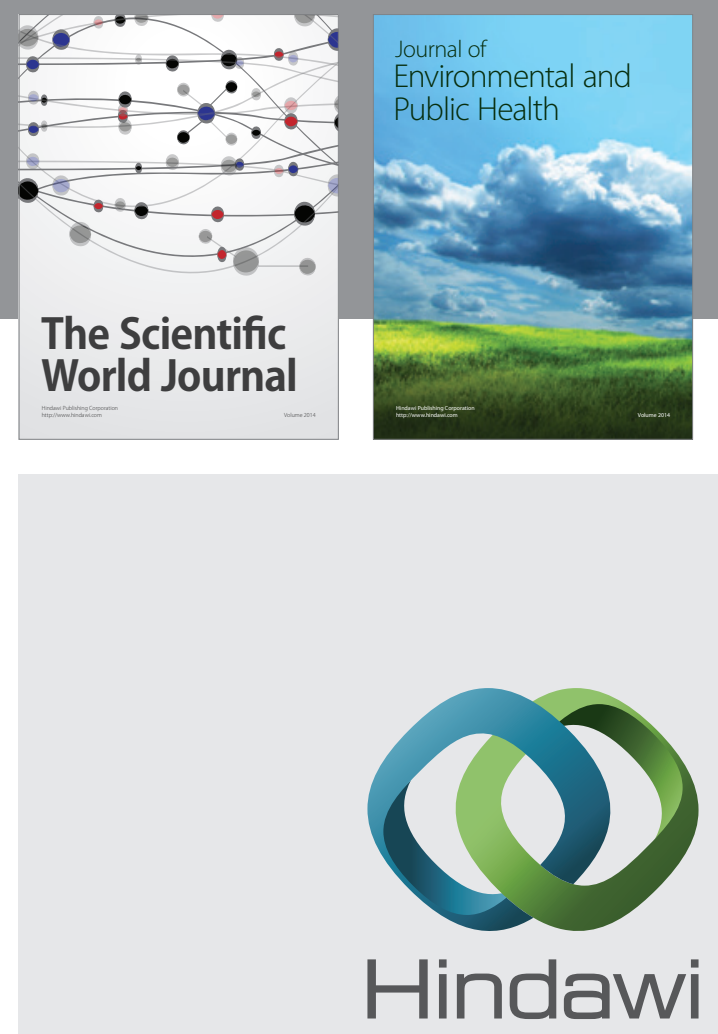

Submit your manuscripts at

http://www.hindawi.com
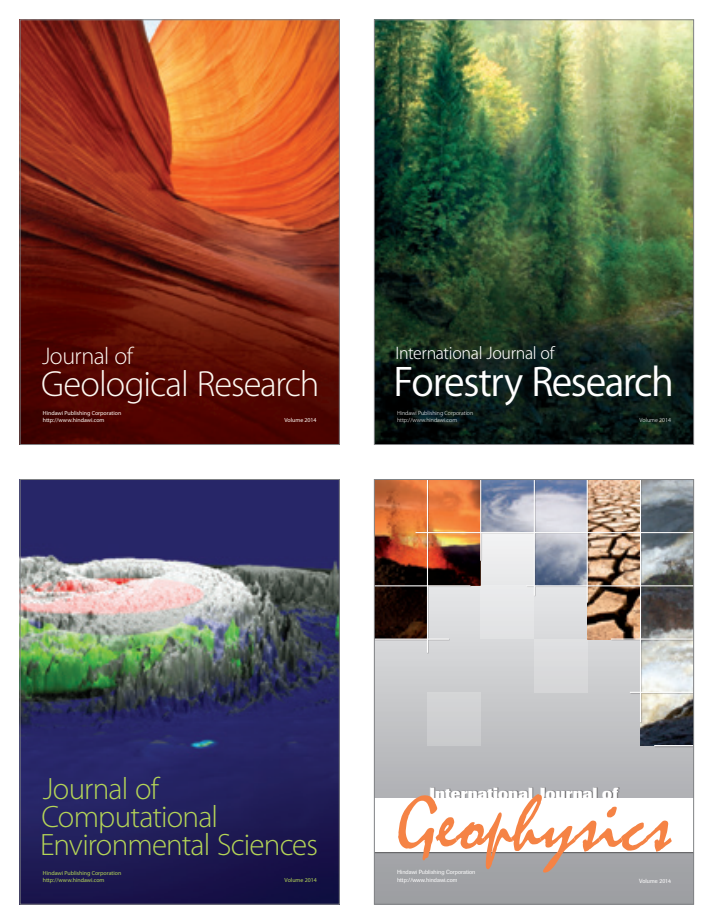
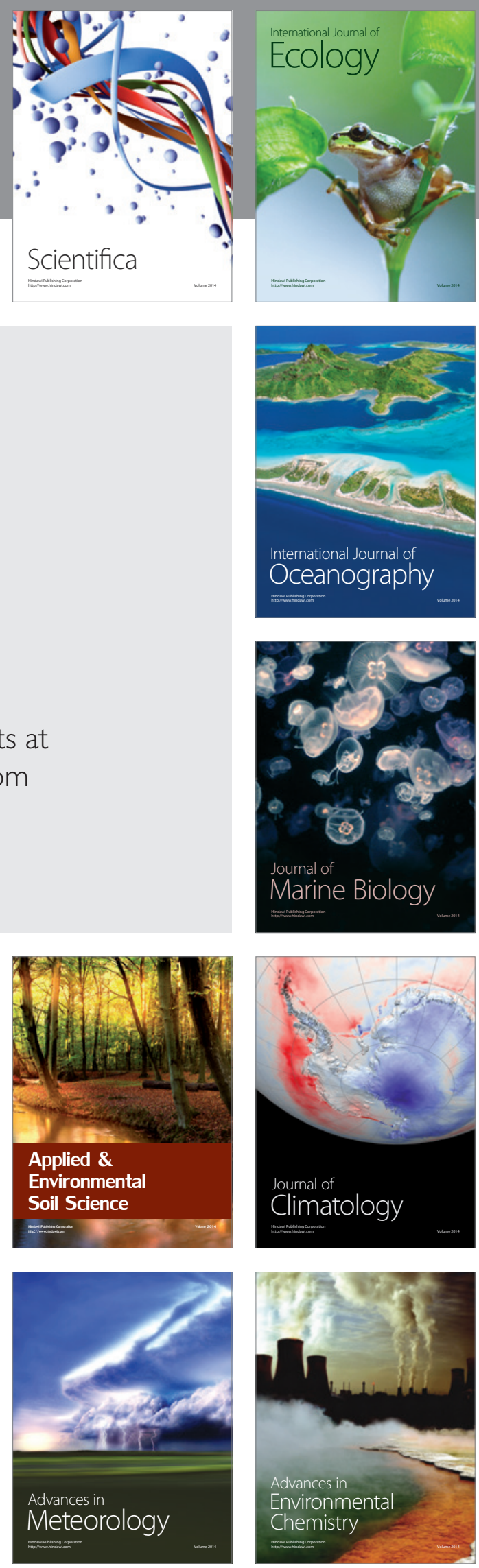